\title{
Employee Performance Evaluation at IPDN North Sulawesi Campus
}

\author{
Ayu Anjani Turangan, Itje Pangkey, Wilson Bogar \\ Manado State University, Tondano, Manado, Indonesia \\ Email: ayuturangan@yahoo.com, itjepangkey@unima.ac.id, wilsonbogar@unima.ac.id
}

\begin{tabular}{l} 
ARTICLE INFO \\
\hline Received: 05-01-2022 \\
Revision: 13-01-2022 \\
Received : 18-01-2022 \\
\hline Keywords: \\
Employee evaluation; \\
performance; employee
\end{tabular}

\section{ABSTRACT}

Human Resources are the main principle in an organization to achieve the expected goals. The performance of employees, especially at the Institute of Domestic Administration (IPDN) North Sulawesi Campus, requires evaluation, especially for civil service educators, namely caregivers. This study aimed to determine the performance and factors that affect the performance of employees (caregivers) at IPDN North Sulawesi Campus. The research used a qualitative approach, while the data collection techniques in this study are observation, interviews, and documentation. The informants in this study were the Head of the Civil Service Administration, the Head of the Parenting Subdivision, the employees (caregivers), and the IPDN Praja North Sulawesi Campus. In general, the results of this research are; 1 ) The performance of employees (caregivers) of IPDN North Sulawesi Campus is in a reasonably good category, this is based on the results of research where from five employee performance indicators, there are still two indicators included in the good enough category, namely "service orientation and work discipline, 2) Factors that affect the performance of employees (caregivers) of IPDN North Sulawesi Campus, there are four namely a) HR development, b) work motivation, c) supervision and d) work environment. It can also be seen that of the four factors that affect employee performance, only one factor supports the performance of IPDN North Sulawesi Campus employees, namely the work environment. In comparison, the other factors are HR development and work motivation. Furthermore, supervision does not support IPDN North Sulawesi Campus employees (caregivers) taking out the job.

\section{Introduction}

Human Resources are the principal capital in moving every activity and program in an organization to achieve the expected goals. Humans are potential and strategic resources. Humans have great potential in life if they want to develop their existing potential.

Humans have a remarkable ability to grow and develop. Therefore, capacity building and the management and maintenance of human resources are absolute. In an organization or institution, humans are also referred to as employees. If an organization or institution wants to progress and be successful in achieving its goals and compete with other organizations or institutions, competent employees are needed in their fields.

Employees have a significant role in implementing all activities in an organization or institution. The role of employees is so important to determine success in achieving organizational or institutional goals. The employees themselves determine the achievement of organizational goals. For this reason, employees who have the potential, knowledge, and productivity are needed to maximize the performance and effectiveness of the relevant organizations so that the organization's goals can be achieved.

The performance of employees, especially at the Institute of Domestic 
Administration (IPDN) North Sulawesi Campus, requires evaluation, especially for civil service educators, namely caregivers. Caregivers are educators stipulated in the Minister of Home Affairs of the Republic of Indonesia number 42 of 2018 concerning the Status of Domestic Government Institutions.

In IPDN, Education is carried out through a centralized Tri Tunggal system consisting of Teaching, Training, and Parenting. The part that plays the most role in shaping the behavior and personality of the Praja is the Parenting section. The success of the parenting pattern depends on the performance of the civil servant caregivers. The civil servant caregivers must always be professional in carrying out their primary duties and functions.

Caregivers have duties and responsibilities for each student member, namely the Praja, who temporarily studies at the IPDN Campus. As for the job description of Caregivers, among others are; (1) prepare materials for rules and regulations and discipline enforcement, (2) evaluate the implementation of the rules and enforcement of the Praja discipline, (3) collecting data and information on implementing public order and discipline enforcement, (4) prepare and provide advice and consideration for imposing disciplinary penalties to the Head of the PDPP unit, (5) reporting on the implementation of the examination in enforcing discipline and investigating the Civil Service, and (6) carry out other tasks assigned by the Head of Section.

The role of caregivers in the educational process is essential. In the case that occurred at the IPDN Campus in North Sulawesi, caregivers rarely come to the office, are late, and do not even care about their work and responsibilities. This indicates a lack of care from the caregiver for the responsibilities assigned to him. The Institute of Domestic Administration (IPDN), as an official higher education institution under the Ministry of Home Affairs (Kemendagri), has the main task of producing quality core cadres of domestic government. However, how can IPDN produce quality cadres while educators, especially caregivers, cannot carry out their obligations according to existing regulations? Based on the explanation of the problems above and realizing how strong employee performance is, the authors are interested in researching and evaluating employee performance at the IPDN Campus in North Sulawesi, with the title "Evaluating Employee Performance at IPDN North Sulawesi Campus."

Referring to the background above, the focus and formulation of the problems discussed are: How is the performance of the employees (caregivers) at IPDN North Sulawesi Campus?

Based on the formulation of the problem above, the objectives to be achieved in this study are to find out how the performance of caregivers at IPDN North Sulawesi Campus and what factors affect employee performance (caregivers) at IPDN North Sulawesi Campus.

\section{The Definition of Performance}

Performance is the result or level of success of a person as a whole during a specific period in carrying out tasks compared to various possibilities, such as work standards, targets or targets or criteria that have been determined in advance and have been mutually agreed upon (Rivai, 2014).

Another opinion was put forward by Simamora (2009), which states that performance is the result of work from a particular process carried out by all organizational components on resources, data, and informal policies, and a specific time used is referred to as input. Furthermore, Husnan dan Heidjrachman (2012) also defines performance as a description of the achievement level of the activity's implementation in realizing the goals, objectives, mission, and vision of the organization contained in the planning strategy.

Theoretically, Sutrisno (2013) concludes that employee performance results from employee work seen in aspects of quality, quantity, working time, and cooperation to achieve goals that the organization has jointly set. In line with the opinion of Anwar (2010), which states that employee performance is the result of work in quality and quantity achieved by an employee in carrying out his duties by the responsibilities given to him. Employee performance is work achieved by a person carrying out the tasks assigned to him based on skills, experience and sincerity, and time (Simamora, 2009). 


\section{Employee Performance Indicators}

Indicators for measuring employee performance, based on Government Regulation Number 46 of 2011 as quoted by Sutrisno (2013) that ASN performance appraisal is assessed based on work behavior as measured by service orientation, integrity, commitment, discipline, and cooperation with the following explanation: which is measured from aspects of service orientation, integrity, commitment, discipline, and cooperation, there are:

\section{a). Service orientation}

Service orientation is employees' attitude and work behavior in providing the best service to those served, including the community, superiors co-workers, co-workers, related work units, and/or other agencies. According to (Puspawati, 2016), public services are various government activities that aim to meet the needs of the community in the sense of goods and services (P. 155).

\section{b). Integrity}

In carrying out the duties, employees are honest, sincere, never abuse the authority, and take the risk. Integrity implies consistency between actions and values, meaning that integrity is employees' ability to carry out the duties to be honest, sincere, and never abuse the authority and dare to take the risk.

\section{c). Commitment}

Employees strive to uphold the state ideology of Pancasila, the 1945 Constitution of the Republic of Indonesia, the Unitary State of the Republic of Indonesia (NKRI), Bhinneka Tunggal Ika and government plans to be able to carry out the duties efficiently and effectively and prioritize official interests rather than personal and/or group interests based on the duties, functions and responsibilities as an element of the state apparatus towards the organization in which they work. Employee commitment in advancing the organization is essential in order to improve employee performance. According to Hasibuan (2010), organizational Commitment is defined as a) a strong desire to remain as a member of a particular organization, c) a desire to strive according to the wishes of the organization; and d) Certain beliefs and acceptance of organizational values and goals

\section{d). Discipline}

Discipline is individual awareness and willingness to obey all organizational rules and applicable social norms (Hasibuan, 2010). The discipline factor plays a significant role in carrying out employees' daily tasks. An employee with a high level of Discipline will continue to work well even without being supervised by superiors. A disciplined employee will not steal work time to do other things with nothing to do with work. Likewise, employees who have Discipline will obey the existing regulations in work discipline with high awareness without any sense of coercion.

\section{e). Cooperation}

Citing the opinion of Siagian (2014) states that the factor that needs to be considered by the organization to make the performance of its human resources is good is to instill and create cooperation or work cohesiveness among employees. This is because the organization consists of personnel who work together and are interconnected. These personnel works together to carry out various organizational tasks within an organization, including determining the goals to be achieved.

\section{The Factors Affecting Performance}

The factors that affect employee performance according to Danang (2011) are:

\section{Human Resources Development}

There are several factors that can improve employee performance, one of which is to develop human resources. Quoting the opinion Anwar (2010) states that to improve the quality of human resources so that it has an impact on improving employee performance, it is by developing human resources. The purpose of developing Human Resources, according to Martoyo (2011) is to improve the abilities, skills, and attitudes of employees so that they are more effective and efficient in achieving program goals or organizational goals.

\section{Work motivation}

Motivation is a process of influencing or encouraging from outside a person or workgroup so that they want to carry out something that has been determined (Samsudin, 2015). Motivation can also be interpreted as a driving force intended as a natural urge to satisfy and maintain life.

\section{Supervision}

Terry (in Hasibuan, 2010) supervision can be defined as the process of determining, what should be achieved, namely standards, what is being done, namely implementation, assessing implementation, and if necessary, 
making improvements so that implementation is under the plan that is in line with standards.

\section{Work Environment}

The dominant physical work environment affects employee morale. It is reasonable because employees will contribute a good performance if supported by good work facilities. It is related to the opinion Kartono (2017) that work facilities are supports that can increase employee morale at work. With these work facilities, fulfilled employees can be faster, more precise in carrying out the job.

\section{Method}

\section{Research Approach}

In this study, researchers used qualitative research methods. Qualitative research is used to examine the condition of natural objects, where the researcher is the key instrument.

\section{Research focus}

Judging from the qualitative approach chosen by the author in this study, the author determines the focus of the research based on a qualitative approach. The research focus is on the essence of the research to be carried out. The focus of research is essential so that research can be directed. Therefore, the focus of the research to be investigated relates to the formulation of the research problem, about the performance of employees at IPDN North Sulawesi Campus, especially in the Educator Division, namely Caregivers (Tenaga Pendidik) who are responsible for character building for Praja who are studying at the IPDN North Sulawesi Campus.

\section{Research sites}

The research location is the place where the author conducts research. Determination of research location is important and related stage in qualitative research. The stipulation of the research location means that the object and research objectives have been determined to facilitate the author in conducting research. This research was conducted at the Institute of Domestic Administration (IPDN) North Sulawesi Campus, located at Tampusu Village, Remboken District, Minahasa Regency. The implementation time of this research is from September 2020 to November 2020.

\section{The Type of Data Source}

The Type of Data Source

In this study, the authors use 2 types of data sources, namely:
1. Primary Data is a source of data obtained directly by researchers from the source in interviews, polls from individuals or groups, and the results of observations of an object, event, or test result.

2. Secondary Data is a source of research data obtained through intermediary media or indirectly related to the object of research in this case in the form of books, records, or existing evidence, archives, both published and unpublished in general.

\section{Data Collection Techniques}

1. Observation

2. Questionnaire

3. Documentation

\section{Data Analysis Technique}

1. Data Reduction

2. Presentation of Data The presentation of data is

3. Making Conclusions/Verification

\section{Results And Discussion \\ The Overview of IPDN North Sulawesi Campus \\ The Institute of Domestic} Administration, commonly abbreviated as IPDN, is a government-owned higher education institution engaged in civil service that aims to produce government cadres who are competent, have character, and have personality. The Institute of Domestic Administration organizes educational programs, including Diploma IV, Undergraduate, Postgraduate and Civil Service Professional Programs. This campus classifies students into two, namely Praja and Students. Praja is the designation for students in diploma and undergraduate programs, while students are called students in postgraduate and civil service professional programs.

IPDN has a vision, namely "To become a trusted Civil Service Higher Education in producing government cadres who are competent, have character and personality". IPDN organizes educational programs with a boarding school system, consisting of Teaching, Training and Parenting. This civil service higher education is held at IPDN Jatinangor Campus and IPDN Cilandak Campus as well as at 6 (six) other regional campuses, namely:

1.) IPDN West Kalimantan Campus in Pontianak

2.) IPDN North Sulawesi Campus in Minahasa Regency. 
3.) IPDN South Sulawesi Campus in Gowa Regency.

4.) IPDN West Nusa Tenggara Campus in Central Lombok Regency.

5.) IPDN Papua Campus in Jayapura.

6.) IPDN West Sumatra Campus in Bukit Tinggi.

Regional IPDN Campuses have been operating since 2009 based on the Regulation of the Minister of Home Affairs Number 39 of 2009 concerning the Organization and Work Procedure of IPDN. As a research location for researchers, IPDN North Sulawesi Campus organizes Civil Service Education Programs with two Faculties and three Study Programs, namely the Faculty of Community Protection with the Population and Civil Registration Study Program and the Faculty of Government Management with the Sector Human Resources Management Study Program. Public and Regional Government Administration Study Program. IPDN Regional Campuses are led by the Director, assisted by three Deputy Directors (according to Article 135 paragraph 3 of the Regulation of the Minister of Home Affairs Number 43 of 2018 concerning Organization and Work Procedures of IPDN), Structural Officers, Educators and Education Personnel.

\section{Description of Research Result Data}

The achievement of the vision and mission of the organization is the final target of the implementation of every task in the organization. Employee understanding of the goals, vision and mission of the organization is essential because the achievement of the ultimate goal of an organization is determined by the people in the organization how to achieve the goals, vision and mission of the organization, meaning that the progress of the organization depends on the human resources.

Acknowledge the performance of employees trying to learn and understand the performance results possessed by employees in an organization. In other words, knowing the performance of employees becomes very important or has an essential strategy. Information about employees, indicators and factors that influence employee performance is critical to know. The analysis can be used as an evaluation to assess the failure of the implementation of the tasks and functions assigned to the employees.

\section{Employee Performance (Caregiver) at IPDN North Sulawesi Campus}

Employee performance is the work achieved by all employees in an organization by the authorities and responsibilities to achieve organizational goals. Performance in the organization is the key to the success or failure of the organizational goals that have been set. Talking about organizational performance and goals cannot be separated from anyone who exists and runs the organization, that is human resources. As an organizational element, human resources have a critical role in carrying out functions in the context of organizational progress. The following are the results of research related to IPDN North Sulawesi Campus employees (caregivers) Government Regulation Number 46 of 2011 as quoted by Sutrisno (2013), which is measured from aspects of service orientation, integrity, commitment, discipline, and cooperation, as follows:

\section{Interview Results Regarding Service Orientation}

Service orientation in this research is to find out hpw far IPDN North Sulawesi Campus employees (caregivers) provide full service to IPDN North Sulawesi Campus Prajas, namely a) Fostering, supervising, supervising, controlling, and encouraging employees consistently and sustainably, b) creating an atmosphere which is conducive to private life under applicable norms, and c) Assessing, directing, reporting, reporting under applicable regulations. The results of the author's interview with Randy Rival Wuntu as the Head of the IPDN North Sulawesi Campus Public Administration on October 19, 2020, stated that:

"Basically, the overall service provided by IPDN North Sulawesi Campus employees to IPDN North Sulawesi Campus Prajas has been quite satisfactory, there are no significant problems, running smoothly, but during the Covid-19 pandemic, it has more or less impact on the community. services provided by employees (caregivers), for example, before the Covid-19 pandemic, caregivers routinely scheduled evaluation activities once a week, providing guidance and direction to Praja, but since March 2020, such activities have been carried out once a month or even every two months, This is due to the government policy 
regarding the prohibition of crowding and the prohibition of holding events that have the potential to gather large crowds."

Furthermore, based on the author's interview with Richard Marshel Hilkia Umbas as Head of the IPDN Care Subdivision, North Sulawesi Campus on October 19, 2020, stated that:

"The job descriptions of caregivers include: a). Prepare materials for rules and regulations and discipline enforcement, $b$ ). Carry out evaluations of implementing regulations and enforcement of Praja discipline, c). Collecting data and information on the implementation of rules and enforcement of Civil Service discipline, d). Prepare and provide advice and consideration for imposing disciplinary penalties to the Head of the PDPP unit, e). Reporting on the implementation of the examination in the context of enforcing discipline and investigating the Civil Service, e). Carry out other tasks assigned by the Head of Department. The results of our observations so far, the services provided by caregivers to IPDN Prajas, especially in the midst of the Covid-19 pandemic, are not running optimally, this is of course a homework for us, to find solutions or solutions, how to keep running service programs without having to ignoring the government's policy of prohibiting gatherings in the midst of the Covid-19 pandemic"

Those statement was confirmed by Dano Arfan Saifoeddin as an employee (caretaker) of IPDN North Sulawesi Campus on October 19, 2020, stating that:

"In general, service activities provided by employees (caregivers) to IPDN Praja North Sulawesi Campus such as evaluation, coaching, discipline enforcement, are less effective and run optimally. The existence of the Covid-19 pandemic indirectly affects services at IPDN North Sulawesi Campus, including services provided by employees (caregivers) to IPDN Prajas. It must be admitted that even though the evaluation, coaching, and disciplinary enforcement services are a bit hampered, we as caregivers have hope that this kind of activity program can still run even though it is not $100 \%$ maximum".

In line with the opinion of Nadia Eunike as the IPDN Praja North Sulawesi
Campus from North Sulawesi registration on October 19, 2020, stated that:

"It must be admitted that to some extent the services provided by IPDN North Sulawesi Campus (caregivers) employees experienced several obstacles, especially during the Covid-19 pandemic, for instance, the lack of intensity of services related to evaluation, coaching, enforcement of discipline, this was due to the activities which has to be done face-to-face and has the potential to gather a large number of people"

\section{Interview Results Regarding Integrity}

Integrity in this study is to find out the extent to which employees (caregivers) are consistent in being honest in carrying out the job, sincere and never abuse the authority and dare to take the risk at work. The results of the author's interview with Randy Rival Wuntu as Head of the Public Administration of IPDN North Sulawesi Campus on October 19, 2020, stated that:

"Integrity is something that is very important for every employee, employee integrity towards the organization will lead employees to get good work results, integrity will support other aspects such as having an impact on work quality, commitment, discipline and even employee leadership. It is even more important that human resources have high integrity than human resources who have a higher level of intelligence, what is the use of individual intelligence if it is not accompanied by good integrity, does not contribute anything to the quality of work and other aspects, talks about the integrity of the IPDN North Sulawesi Campus employees (caregivers) as a whole is quite good, but do not turn a blind eye there are still employees with low integrity, for example carrying out dishonest tasks, abusing authority, but all of that becomes homework for us as superiors, to foster subordinates so that In the future, we will uphold a sense of integrity in carrying out our work"

The above statement was confirmed by Richard Marshel Hilkia Umbas as Head of the North Sulawesi Campus IPDN Care Subdivision on October 19, 2020, stating that:

"Integrity is a mindset and character that is in accordance with applicable norms and regulations that are produced through a long process, it can also be said that integrity is acting consistently in accordance with 
policies, codes of ethics, and regulations. Employees are organs of the running of a government organization, when in that organ there is a chronic disease then the whole government will be disrupted. In essence, the role of employees is very vital in a government organization. If this employee works well, prioritizing the interests of the task above personal interests, then the employee can be said to be working with full integrity. With regard to the integrity of the IPDN employees of the North Sulawesi Campus, in general the integrity of the employees (caregivers) is quite good, the employees continue to carry out their duties with integrity".

In line with the opinion of Hary Cahya Putra as an employee (caretaker) of IPDN North Sulawesi Campus on October 19, 2021, stated that:

"Integrity is synonymous with being honest in carrying out work, sincerely working, never abusing their authority and daring to take the risk of their actions. Our observation is that the integrity of IPDN North Sulawesi Campus employees (caregivers) have integrity in carrying out their work, although there are also employees who have low integrity, for example, not working sincerely due to lazy work, but overall the integrity of the IPDN North Sulawesi Campus employees (caregivers) is going quite well."

Agree with Muhammad Azharuddin as IPDN Praja North Sulawesi Campus from Central Kalimantan on October 19, 2021, stated that:

"The integrity of the IPDN North Sulawesi Campus employees (caregivers) in carrying out the duties is quite good, the North Sulawesi Campus employees (caregivers) have worked sincerely, not taking advantage of the situation to make irregularities, even if there are IPDN North Sulawesi Campus employees (caregivers) who lack integrity in carrying out their duties. work, I think that is only a small part of it"

The results of the interviews are related to the performance of IPDN North Sulawesi Campus employees (caregivers) seen from the overall integrity aspect, it is known that employees have good integrity in carrying out the job, this is reinforced by the document of the results of the Employee Performance Target (SKP) assessment in 2020. in the "good" category. This means that the employee (caregiver) continues to work sincerely, does not take advantage of the situation to make deviations, although there are also a small number of employees (caregivers) who lack integrity in carrying out the job, for example, they are less sincere in their work because they are lazy to work, but Overall, the integrity of the IPDN North Sulawesi Campus employees (caregivers) has gone quite well.

\section{Discussion of Research Results}

The success of an organization is commonly determined by the quality of human resources or the people who work in it. The employee is the state apparatus or the main element of human resources and is the spearhead who plays an important role as a tool to achieve the goals of the agency that oversees it or where the employee works. The achievement of agency/organizational goals does not only depend on modern equipment, but also on the people who carry out the work.

\section{Employee Performance Analysis (Caregiver) at IPDN North Sulawesi Campus \\ Service Orientation Analysis}

The results of the study related to the performance of the IPDN North Sulawesi Campus employees (caregivers) seen from the aspect of service orientation to civil servants, it can be seen that it is not running effectively and optimally even if referring to the document on the results of the Employee Performance Target (SKP) assessment in 2020 it is in the "good enough" category. The ineffective and maximal performance of IPDN North Sulawesi Campus employees (caregivers) is seen from the aspect of service orientation such as evaluation activities, providing guidance and direction to Praja which was initially routinely carried out once a week. However, since March 2020, such activities have been carried out once a month or even twice. This is due to the government's policy of prohibiting crowds and holding events that can gather large crowds.

The State Civil Apparatus, including employees (caretakers) of IPDN North Sulawesi Campus are the most critical assets spearheading in carrying out the duties and responsibilities at IPDN North Sulawesi Campus. The essence of the duties and responsibilities of government employees is to carry out service functions. Quoting the 
opinion of (Ndraha, Hsiao, \& Wang, 2017) relating to government employees stated that the essence of government employees is to provide services to the public because essentially government employees are "public service", the main function of government employees is to organize good governance as the government's duty to provide excellent service to the public, then employee orientation must focus on customers (P. 115). Thus the context should be that the directed to provide quality services to customers, both internally and externally.

The services provided by IPDN North Sulawesi Campus employees are based on the Decree of the Minister of Home Affairs No. 157 of 2004 concerning Guidelines for Parenting Praja Educational Institutions at the Ministry of Home Affairs, Articles 13, 14, 15 CHAPTER VII concerning the Duties, Obligations and Authorities of Caregivers, there are (1) caregivers are tasked with fostering, guiding, supervising, controlling, and evaluating Praja consistently and continuously, (2) caregivers are required to create a conducive atmosphere for civil service life to conform to applicable norms, and, (3) caregivers are authorized to assess, direct, suggest a report by applicable regulations.

\section{The Analysis Regarding to the Work Environment}

The interview results show that the work environment has an impact and affects employee performance. It can also be seen that the IPDN North Sulawesi Campus has made every effort to provide the fulfillment of employee work facilities (caregivers), both in quality and quantity, for example, by providing a set of office equipment facilities (tables, chairs, laptops, printers, wi-fi, stationery), provide housing facilities and their accessories and provide operational vehicles. The factor that is expected to improve employee performance is the work environment. The work environment is one of the conditions, both physical (work environment, building) and non-physical (work comfort, work security, work relations) that are around employees in doing their work which will determine passion and enthusiasm for work so that it will determine the achievement of employee performance.

Employees' high and low performance is influenced by the work environment, both physically such as work facilities and nonphysically such as work comfort and security. The work environment also dominantly affects employee performance; this is quite reasonable because basically, employees will contribute to good performance if a good work environment is supported. This is under the opinion of Darmodiarjo (2017:16) that the work environment is one of the conditions both physical (work facilities) and non-physical (work comfort, work security, work relations) that are around employees in doing the work which will determine the passion and enthusiasm for work that will determine employee morale achievement. According to Nitisemito (2012: 184), the work environment is everything around the workers that can influence in carrying out the assigned tasks. Humans will be able to run the activities well and achieve optimal results if supported by appropriate, healthy and adequate environmental condition.

An environmental condition is said to be suitable, healthy and adequate if humans can run the activities optimally, safely, and comfortably. Therefore, every organization is obliged to provide a healthy work environment for its employees to work by the organization's wishes to achieve organizational goals. The fulfillment of work facilities, comfort, and safety of employees at IPDN North Sulawesi Campus will encourage the emergence of employee morale (caregivers), which can improve employee performance and services to the needs of civil servants be carried out effectively and efficiently.

The provision of adequate infrastructure has become mandatory to support employees in carrying out the work. The dominant physical work environment affects employee morale; it is reasonable because employees will contribute to good performance if supported by good work facilities. This is by the opinion Kartono (2017) that work facilities are supports that can increase employee morale at work. With these work facilities fulfilled, employees can be faster and more precise in carrying out office work.

Quoting Agustino's opinion (2010:156) which states that non-physical work environments such as facilities and infrastructure, work facilities are a measuring tool that will affect employee performance in implementing a policy, because the availability 
of adequate work facilities influences the implementer in carrying out an activity. Moreover, fit for use. The dominant work environment affects the performance of the implementer, it is pretty reasonable since the implementer will contribute to good performance if good work facilities support it. In line with the opinion of (Priyambodo, Tjiptono, \& Suyoto, 2012) states that work facilities are supporters that can improve the performance of the implementer at work, with the fulfillment of these work facilities, the implementer can be faster, more precise in carrying out office work (P. 123). It is different from Hasibuan (2010), which states that the availability of the resources needed to implement the policy will automatically facilitate its implementation. These resources are in the form of human resources, expertise, funds, facilities, etc. A policy requires good resources, both human resources and work facilities. Humans are an essential resource in determining success in implementing policies. Each stage or process of the journey of a policy requires quality human resources by the work required by the established policy.

Human resources and work facilities are one of the factors that influence the implementation and success of a policy. In contrast, the human resource components that can support the implementation of policies can be tangible, among others, staff, skills and appropriate qualifications. In contrast, work facilities are the tools used in implementing those policies.

Every organization is formed and established because of specific goals to be achieved. To achieve these goals, various resources are needed as factors, including employees or human resources. Humans are the essential element and other elements possessed by an organization such as money, materials, machines, work methods. Human resources or employees are also the essential assets in an organization because they are the source that directs the organization in achieving its goals. Employees in the agency function as implementers of the main tasks of the organization. Human resources are an essential factor for every organization because, without human resources, the goals and objectives of the organization will not be achieved as planned. Therefore, the role of human resources is crucial in every organization. The importance of the role of human resources for every organization is expected to improve employee performance.

Humans in a re-emphasis on the philosophy of man behind the gun, the wheel of organization in an organization is also seen as a resource or driver, this is very dependent on the behavior of humans who work in it. The behavior in question is not only enough to come and go home from work on time, always dress neatly and be diligent. However, employees are expected to carry out their duties effectively and efficiently with complete dedication and creativity, which is expected to achieve organizational goals.

Seeing the importance of employees in an organization or agency, it is no exaggeration to say that employees are the most important asset and have a direct impact on the organization compared to other resources (Abhimanyu, 2020). Whether or not an organization is effective does not lie in the size of the organizational structure but how its ability to utilize existing employee resources. Seeing the importance of employees (caregivers) as the spearhead in achieving organizational goals, for this reason, IPDN North Sulawesi Campus officials should pay more attention to factors that affect performance so that in the end it leads to improving employee performance (caregivers).

\section{Conclusion}

Based on the theoretical study, the results of interviews as well as the results of the analysis and findings in the field, it can be concluded as follows:

The performance of employees (caretakers) of IPDN North Sulawesi Campus is in a pretty good category, this is based on the results of research where from 5 (five) employee performance indicators, there are still 2 (two) indicators that fall into the pretty good category, namely "service orientation and discipline". It means that the service of employees (caregivers) to civil servants is indicated to be still not optimal, and work discipline of employees (caregivers) is still low, there are still IPDN officers on the North Sulawesi Campus who skip work, do not come to scheduled work, and there are still employees who work but not by applicable official rules.

There are 4 (four) factors that affect the performance of IPDN employees (caretakers), 
namely a) HR development, b) work motivation, c) supervision, and d) work environment. It can also be seen that of the 4 (four) factors that affect employee performance, only 1 (one) factor supports the performance of IPDN North Sulawesi Campus employees, namely the work environment. In comparison, the other 3 (three) factors are HR development, work motivation. Moreover, supervision does not support IPDN North Sulawesi Campus employees (caregivers) in carrying out their work.

\section{Suggestions}

Based on the results of the study, the suggestions that the authors propose in this research are:

Improving service orientation carried out by IPDN North Sulawesi Campus employees (caregivers), IPDN North Sulawesi Campus officers should be able to take advantage of technological sophistication, for example conducting long-distance teleconferences, providing services through Zoom as media, continuing to carry out and implementing activity programs by prioritizing health protocols, gather a limited number of people so that services can continue to run even during the Covid-19 pandemic.

Improving the work discipline of IPDN North Sulawesi Campus employees (caregivers) should be superiors of each field can increase the frequency of supervision and provide strict, proportional and impartial sanctions if there are employees (caregivers) who work disciplined. Furthermore, their respective superiors should Offer rewards for employees (caregivers) with high work discipline. It is hoped that employees (caregivers) will remain enthusiastic and highly motivated to carry out work during the Covid19 pandemic.

Human resource development at IPDN North Sulawesi Campus should be further improved, for example, by increasing the frequency of providing training, seminars related to the primary duties of employees or inviting competent resource persons to share. Thus it is expected to increase the knowledge and skills of employees in carrying out work, so that employee (caregiver) performance is more improved.

The frequency of direct supervision of the leadership needs to be increased; the leadership must carry out inspections more often and carry out routine maintenance every day, and go into the field when the IPDN North Sulawesi Campus employees (caregivers) are working, so it is hoped that employees will be more motivated to work.

IPDN North Sulawesi Campus pays more attention to the basic needs of employees (caregivers) because basically, employees work to meet basic needs, namely clothing, food, housing, and individual welfare. The solution is by giving appropriate incentives, giving bonuses outside of salary if employees (caregivers) work outside office hours, providing other compensation such as additional transportation money, food allowance. Thus it is expected to increase employee motivation in working which in turn is expected to improve employee performance.

\section{References}

Abhimanyu, S. (2020). Urban Growth Analysis and Modelling Based on Socio-Economic Agents Using Cellular Automata. 2020 IEEE India Geoscience and Remote Sensing Symposium (InGARSS), 42-45. IEEE. Google Scholar

Anwar, P. (2010). Manajemen Sumber Daya Manusia. Jakarta: Gramedia. Google Scholar

Bogar, W. (2020). Pengaruh Lingkungan Kerja dan Karakteristik Pekerjaan terhadap Burnout, Kepuasan Kerja, Komitmen Organisasi dan Intention to Leave (Studi pada Pegawai Perum Pegadaian di Sulawesi Utara). Jurnal Aplikasi Manajemen, 9(4), 1465-1475. Google Scholar

Danang, S. (2011). Sumber Daya Manusia Cetakan. Yogyakarta: CAPS.

Hasibuan, M. (2010). Manajemen Sumber Daya Manusia Dasar Kunci Keberhasilan. Jakarta: CV Haji Mas Agung. Google Scholar

Husnan, \& Heidjrachman. (2012). Manajemen Sumbaer Daya Manusia Perusahaan. Bandung: PT. Remaja Rosda Warga. 
Kartono, K. (2017). Iklim dan Lingkungan Pegawai. Bandung: CV Pustaka Setia.

Martoyo, S. (2011). Latihan dan Pengembangan Sumber Daya Manusia. Bandung: Mandar Maju.

Ndraha, Nodali, Hsiao, Hsin I., \& Wang, Wayne Chung Chih. (2017). Comparative study of imported food control systems of Taiwan, Japan, the United States, and the European Union. Food Control, 78, 331-341. Google Scholar

Pangkey, I., Mawitjere, W. R., Langkai, J. E., \& Wawointana, T. (2018, October). The Influence of Community Kinship Towards Effectiveness of Student's Activity. In 1st International Conference on Social Sciences (ICSS 2018) (pp. 716-721). Atlantis Press. Google Scholar

Priyambodo, Lukas, Tjiptono, F. Suyoto, \& Suyoto, M. (2012). M-Commerce in Indonesia: Problems and Prospects. International Journal of Computer Applications \& Information Technology, 1(2), 71-76. Google Scholar
Puspawati, Dewita. (2016). Studi Kualitatif Wajib Pajak Orang Pribadi Pengusaha Tertentu Untuk Melakukan Pembayaran Pajak Penghasilan (PPh)(Studi Kasus pada Pelaku Social Commerce). Riset Akuntansi Dan Keuangan Indonesia, 1(2), 119-125 Google Scholar

Rivai, B. (2014). Penilaian Prestasi Kerja Teori dan Praktek. Jakarta: PT. Ganudra Pustaka Utama. Google Scholar

Samsudin. (2015). Manajemen Sumber Daya Manusia. Jakarta: PT Prenhalindo.

Siagian, S. P. (2014). Pengembangan Organisasi dan Staf. Jogyakarta: Balai Pustaka.

Simamora, H. (2009). Manajemen Sumber Daya Manusia. Yogyakarta: Graha Ilmu. Google Scholar

Sutrisno, E. (2013). Manajemen Sumber Daya Manusia. Jakarta: Kencana Prenada Media Group. Google Scholar

\section{Copyright holder :}

Ayu Anjani Turangan, Itje Pangkey, Wilson Bogar (2022)

First publication right :

Journal of Social Science

This article is licensed under:

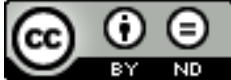

